\title{
SWI/SNF-Related Matrix-Associated Actin- Dependent Regulator of Chromatin Subfamily D Member 2
}

National Cancer Institute

\section{Source}

National Cancer Institute. SWI/SNF-Related Matrix-Associated Actin-Dependent

Regulator of Chromatin Subfamily D Member 2. NCI Thesaurus. Code C19843.

SWI/SNF-related matrix-associated actin-dependent regulator of chromatin subfamily $D$ member 2 (531 aa, $~ 59 \mathrm{kDa}$ ) is encoded by the human SMARCD2 gene. This protein is involved in nucleosome topology, chromatin remodeling and transcriptional regulation. 